\title{
Interpreting dissociations between regular and irregular past-tense morphology: Evidence from event-related potentials
}

\author{
Timothy JUSTUS AND JARY LARSEN \\ VA Northern California Health Care System, Martinez, California \\ Paul de Mornay Davies \\ Middlesex University, London, England \\ AND \\ Diane Swick \\ VA Northern California Health Care System, Martinez, California \\ and University of California, Davis, California
}

\begin{abstract}
Neuropsychological dissociations between regular and irregular English past-tense morphology have been reported using a lexical decision task in which past-tense primes immediately precede present-tense targets. We present N400 event-related potential data from healthy participants using the same design. Both regular and irregular past-tense forms primed corresponding present-tense forms, but with a longer duration for irregular verbs. Phonological control conditions suggested that differences in formal overlap between prime and target contribute to, but do not account for, this difference, suggesting a link between irregular morphology and semantics. Further analysis dividing the irregular verbs into two categories (weak irregular and strong) revealed that priming for strong verbs was reliably stronger than that for weak irregular and regular verbs, which were statistically indistinguishable from one another. We argue that, although we observe a regular-irregular dissociation, the nature of this dissociation is more consistent with single- than with dual-system models of inflectional morphology.
\end{abstract}

Since the publication in 1986 of Rumelhart and McClelland's Parallel Distributed Processing, which included a chapter titled "On learning the past tenses of English verbs," characterizing the acquisition, production, and comprehension of the English past tense has been a major endeavor in cognitive psychology. At the center of the debate lies the issue of whether regular past tensesthose that differ from the present tense by one of three /d/ allomorphs - are generated by a fundamentally different cognitive mechanism than are irregular past tensesthose that have more idiosyncratic relationships between present- and past-tense forms. Dual-system theorists argue that regular past tenses are produced by affixation of a default form (-ed), whereas irregular past tenses are stored in an associative lexical memory as full words (Pinker \& Ullman, 2002). Single-system theorists argue that both regular and irregular morphology can be modeled within a single associative system that maps relationships between phonology, orthography, and semantics (McClelland \& Patterson, 2002).

The contrast between dual- and single-system models is often viewed as a critical case study for psycholinguistics, given that it pits more traditional views that empha- size the special status of grammar (Pinker, 1999) against other theories that have renewed attention to other components of language within a more domain-general context (Elman et al., 1996). The debate has broader relevance for cognitive science, given that the dual-route model is associated with a propositional, symbol-manipulating view of cognition (Marcus, 2001), whereas the single-route model has been driven by the development of connectionism and neural-network modeling. For the neuropsychologist, the past-tense controversy is of interest, given the important role that cognitive and neural dissociations have played in fueling the debate: Dissociations between regular and irregular morphology have been observed in data from acquisition (Brown, 1973; Kuczaj, 1977), psycholinguistics (Kempley \& Morton, 1982; Napps, 1989; Sonnenstuhl, Eisenbeiss, \& Clahsen, 1999; Stanners, Neiser, Hernon, \& Hall, 1979), neuropsychology (Marslen-Wilson \& Tyler, 1997; Tyler, de Mornay Davies, et al., 2002; Ullman et al., 1997), neuroimaging (Beretta et al., 2003; de Diego Balaguer et al., 2006; Jaeger et al., 1996; Sahin, Pinker, \& Halgren, 2006), and electrophysiology (Münte, Say, Clahsen, Schiltz, \& Kutas, 1999; Weyerts, Münte, Smid, \& Heinze, 1996). In fact, the past-tense debate 
is largely one of how to interpret cognitive and neural dissociations.

\section{Neuropsychological Dissociations and the Immediate-Priming Design}

Neuropsychological dissociations in past-tense processing have been reported using an auditory immediatepriming design employing a lexical decision task. Specifically, a past-tense prime is followed by a present-tense target (e.g., looked-look, spoke-speak), and participants decide whether the target is a real word or a nonword. For healthy controls, both regular and irregular past-tense forms have consistently been shown to facilitate a lexical decision to the corresponding present-tense forms, typically with numerically - if not significantly - greater priming for the irregulars (Longworth, Keenan, Barker, Marslen-Wilson, \& Tyler, 2005; Marslen-Wilson \& Tyler, 1997; Tyler, de Mornay Davies, et al., 2002; Tyler et al., 2004). This contrasts with results of experiments in which intervening items are presented between prime and target, which arguably results in full priming for regulars (i.e., as much as identity priming) and only partial priming for irregulars, a difference to which we will return. For aphasic patients, the regular and irregular priming effects in the immediate-priming design have been argued to dissociate, in such a way that patients with damage to left anterior perisylvian regions fail to show priming for regular verbs, but show preserved priming for irregulars (Marslen-Wilson \& Tyler, 1997; Tyler, de Mornay Davies, et al., 2002). One patient with a more posterior lesion showed the reverse dissociation within such an experiment (Marslen-Wilson \& Tyler, 1997), and other patients with posterior lesions have shown more pronounced impairments for the irregular verbs in production tasks (Tyler, de Mornay Davies, et al., 2002; Ullman et al., 1997).

In the earlier years of the debate, such dissociations between regular and irregular verbs were typically taken as prima facie evidence for the dual-system model (e.g., Clahsen, 1999). However, single-system theorists have challenged this interpretation by arguing that the distinction between regular and irregular morphology is not categorical, but rather continuous. In one view, regular morphology is more dependent on phonology, whereas irregular morphology is more dependent on semantics (Joanisse \& Seidenberg, 1999). Thus, deficits in phonology that accompany more anterior brain damage are argued to lead to problems with regulars (Bird, Lambon Ralph, Seidenberg, McClelland, \& Patterson, 2003; Braber, Patterson, Ellis, \& Lambon Ralph, 2005; Lambon Ralph, Braber, McClelland, \& Patterson, 2005; cf. Longworth, Marslen-Wilson, Randall, \& Tyler, 2005; Tyler, Randall, \& Marslen-Wilson, 2002; Ullman et al., 2005), and deficits in semantics that accompany more posterior brain damage are argued to lead to problems with irregulars (Patterson, Lambon Ralph, Hodges, \& McClelland, 2001; cf. Miozzo, 2003; Miozzo \& Gordon, 2005; Tyler et al., 2004). It is important to note that all words are processed within a single network, but with internal dif- ferentiation, in such a way that continuous dissociations between regular and irregular verb processing would be predicted, as opposed to the categorical dissociations predicted by dual-system models. ${ }^{1}$

\section{Previous Event-Related Potential Studies Using Other Experimental Designs}

Rather than focus on the auditory immediate-priming design used in the neuropsychological literature, eventrelated potential (ERP) studies of regular and irregular morphology have focused on other experimental designs - typically using visual stimuli — which we briefly review here.

One design that has been used with a variety of European languages involves presenting participants with correctly and incorrectly inflected regular and irregular words. In German, verbs take either a - $t$ or -en ending in the past participle, with similar frequencies for the two endings. The $-t$ ending is considered to be the regular form. Penke et al. (1997) found that overregularizations of irregular verbs (e.g., *geladet, rather than geladen) produced a left frontotemporal negativity, whereas overirregularizations (e.g., *getanzen, rather than getanzt) did not. A similar result was found using the same design with the German plural system (Weyerts, Penke, Dohrn, Clahsen, \& Münte, 1997), in which $-s$ is argued to be the default form (despite being a very small minority), whereas $-e n,-e,-e r$, and no change are all more common, with the latter three often involving umlauting of the stem. ${ }^{2}$ Similar experiments have been conducted in Italian (Gross, Say, Kleingers, Clahsen, \& Münte, 1998), Catalan (Rodríguez-Fornells, Clahsen, Lleó, Zaake, \& Münte, 2001), and English (Morris \& Holcomb, 2005), although the results of these other studies were not as clear cut.

A second experimental design has employed morphologically related primes and targets in the lexical decision task, but with several intervening items presented between prime and target. As mentioned previously, this delayedpriming technique has a different pattern of results from immediate priming with regard to regular and irregular verbs. In behavioral studies using this design, a pattern of greater priming for the regulars has been (inconsistently) observed (Napps, 1989; Sonnenstuhl et al., 1999; Stanners et al., 1979; cf. Fowler, Napps, \& Feldman, 1985; Hanson \& Wilkenfeld, 1985). N400 effects have been found to be reduced for regular but not irregular verbs, using this design in German (Weyerts et al., 1996), English (Münte et al., 1999), and Spanish (Rodríguez-Fornells, Münte, \& Clahsen, 2002). The rationale for the intervening items, and a potential explanation for the discrepant results in immediate- and delayed-priming designs, is the reduction or elimination of semantic priming, which otherwise dominates the behavioral and N400 priming effects. Semantic priming effects are generally short lived with the lexical decision task (see Joordens \& Becker, 1997, and references therein; cf. Becker, Moscovitch, Behrmann, \& Joordens, 1997). In contrast, the priming between related verb forms at long lags has been argued to be more purely 
morphological, although some have argued that this is at least partly due to episodic effects that are greater for similar primes and targets (Feustel, Shiffrin, \& Salasoo, 1983; Fowler et al., 1985).

A final article of note did employ the immediate-priming design, but attempted to reduce semantic priming in a different way. De Diego Balaguer, Sebastián-Gallés, Díaz, and Rodríguez-Fornells (2005) adapted the technique of Stolz and Besner (1998) in their Spanish-language study of Catalan-Spanish bilinguals: In addition to performing a lexical decision to the target word, participants also performed a letter search on the prime. Using regular, semiregular, and idiosyncratic verbs, these authors found that N400 effects for primed regular verbs were strong in both L1-Spanish and L1-Catalan speakers, the effects for semiregular verbs were weak in both groups, and the effects for idiosyncratic verbs were strong only for the L1-Spanish group. We find it interesting that, despite efforts to reduce semantic priming, this effect was still significant.

\section{The Present Study}

Despite the convention in the ERP literature to present stimuli visually and to use either an incorrect-inflection or delayed-priming design, the neuropsychological dissociations documented using the auditory immediate-priming design remain a critical source of evidence in the pasttense debate, and we wished to complement this chapter of the debate with new ERP evidence from healthy participants. In addition to collecting behavioral data, the use of ERPs provided additional information with regard to the time course and scalp distribution of the associated effects. Specifically, we examined an ERP component known as the N400, a negative wave that peaks at approximately $400 \mathrm{msec}$ following the presentation of a potentially meaningful stimulus, such as a word or a picture (Kutas \& Federmeier, 2000; Kutas \& Hillyard, 1980). The size of the N400 has been shown to reflect the ease of semantic integration into the preceding context, with an inverse relationship between the size of the N400 and the predictability of the stimulus's occurrence, given the context. Thus, a word or picture that has been primed is associated with a reduced N400 component. Far from intending to eliminate semantic contributions to priming, we hoped to observe these ERPs with semantic, phonological, and orthographic contributions intact.

Four types of priming relationships were examined: two between past-tense forms and present-tense forms (regular and irregular) and two between semantically unrelated words that contained phonological and orthographic overlap (pseudopast and orthophono). These were designed as a control for the greater formal overlap between regular past- and present-tense forms. In the pseudopast condition, pairs of semantically unrelated words were chosen as phonological analogues of the regular past tense (e.g., bead-bee). In the orthophono condition, pairs of semantically unrelated words were chosen that differed by some other single phoneme (e.g., bargebar) and contained full orthographic overlap, as well as phonological overlap.
A major question concerned whether any dissociation between regular and irregular priming effects would be better described as categorical, as predicted by the dualsystem model, or continuous, as predicted by the singlesystem model. Thus, our irregular word set contained approximately equal numbers of weak irregular verbs and strong verbs. Weak irregular verbs are similar to regulars in that their past-tense forms end in a dental stop consonant (e.g., spent-spend). These forms may have followed more regular patterns during earlier periods in the history of the English language (see Pinker, 1999). Collectively, the regular verbs and weak irregulars constitute the class of weak verbs. In contrast, strong verbs are truly irregular; their present- and past-tense forms are related by a system of vowel changes known as ablaut, and in many cases there is a third form for the past participle (e.g., speakspoke-spoken; sing-sang-sung). ${ }^{3}$ According to a dualsystem approach, any irregular verb must be listed in the lexicon; thus, no systematic difference should be expected between the processing of weak irregular and strong verbs. Conversely, the single-system approach predicts that any dissociation between regular and irregular morphology should be graded and continuous; thus, differences would be expected across different types of irregularity.

\section{METHOD}

\section{Participants}

Sixteen healthy young adults participated in the experiment ( $25 \pm 4$ years of age; $16 \pm 3$ years of education; 8 female, 8 male; 15 right-handed, 1 left-handed). All participants were native speakers of U.S. English.

\section{Procedure}

Following an informed consent procedure and electroencephalograph (EEG) capping, participants were seated in a soundattenuated booth. Each trial of the experiment began with fixation for $1,500 \mathrm{msec}$, followed by the prime, spoken by the female voice. At 1,400 msec after the onset of the prime (an average of $870 \mathrm{msec}$ interstimulus interval, given mean prime length of $530 \mathrm{msec}$ ), the target was presented, spoken by the male voice. Participants were instructed to identify quickly and accurately whether the target (male) voice was saying a real word or a nonword and to indicate each response by pressing one of two buttons with the left or right thumb. Response mapping was counterbalanced between participants.

\section{Design and Selection of Stimuli}

We selected 1,200 stimulus items to create 600 prime-target pairs according to a 4 (regular, irregular, pseudopast, orthophono) $\times 3$ (primed, unprimed, nonword) design with 50 trials per cell. All cells consisted of 46 monosyllabic prime-target pairs and 4 bisyllabic prime-target pairs. All 600 of the primes and 400 of the targets were real words selected with the aid of the CELEX lexical database (Baayen, Piepenbrock, \& Gulikers, 1995). The remaining 200 items were selected using the ARC nonword database (Rastle, Harrington, $\&$ Coltheart, 2002).

One design constraint that was adopted, given the use of ERP data, was the decision to limit the occurrence of any given word form to a single instance. This was done to avoid the occurrence of N400 reductions due to the second presentation of a word, which has been observed even for extremely large lags (Bentin \& Peled, 1990; Nagy $\&$ Rugg, 1989). The primary consequence of this decision was that items could not be counterbalanced between primed and unprimed conditions. As a result, extreme care was taken to balance the items 
used in the primed and unprimed conditions - as well as the prime words in the nonword condition - on factors such as lemma frequency, syllabicity, word class, number of phonemes, number of letters, and - in the case of irregular verbs - the type of irregularity. This was done simultaneously with the constraint to balance the same factors as closely as possible between the regular, irregular, pseudopast, and orthophono conditions. Further constraints on the selection of stimulus items for each word type were as follows.

Regular verbs. We selected 150 regular verbs and divided them among the primed, unprimed, and nonword conditions. All were the $/ \mathrm{t} /$ or /d/ rather than the /Id/ allomorph, in order to control for syllabicity with the other conditions. Regular past tenses that shared pronunciations with other words ( $\mathrm{packed} /$ pact, missed/mist) were avoided.

Irregular verbs. We selected 150 of the $\sim 180$ irregular English verbs. Modal forms (e.g., could-can, would-will) were avoided, as were words that are typically regularized in U.S. English (e.g., learnt-learn, spilt-spill). The chosen items were divided into primed, unprimed, and nonword conditions as follows: First, to avoid repetition priming, the 26 no-change irregulars (e.g., put) were used as primes only in the nonword condition. The remaining 45 weak irregulars in the set (e.g., spent-spend) were divided between the primed $(n=23)$ and unprimed $(n=22)$ conditions. The rest of the words in the three conditions ( $n \mathrm{~s}=27,28$, and 24) were strong verbs (e.g., spoke-speak), or, in two cases, suppletive verbs (was-is, went-go). Care was taken to distribute the subordinate families of irregular verbs as evenly as possible throughout the three conditions, given these constraints.

Pseudopast. We selected 50 pairs of semantically unrelated words in which the prime word differed from the target word by the addition of $/ \mathrm{t} /$ or $/ \mathrm{d} /$ in a manner phonologically consistent with the regular past tense. Potential stimuli overlapping with items in the verb conditions (e.g., field-feel, bide-buy) and sharing pronunciations with regular verbs were avoided. Given the small number of appropriate monosyllabic pairs available in English, these 50 pseudopasts were all used in the primed condition. The items in the unprimed and nonword conditions were designed by choosing items of the same word class, frequency, and, to the extent possible, number of phonemes and letters as in the primed condition.

Orthophono. We selected 50 pairs of semantically unrelated words in which the prime word differed from the target word by the addition of a single phoneme and one or two letters. Unlike in the pseudopast condition, this addition was not phonologically consistent with any regular past-tense form, and the spelling of the shorter target word was completely contained within the spelling of the longer prime word. These 50 orthophono prime-target pairs were all used in the primed condition. As in the pseudopast condition, the items in the unprimed and nonword conditions were designed by choosing items of the same word class, frequency, and number of phonemes and letters as in the primed condition.

The entire stimulus set may be viewed in the Appendix.

\section{Stimulus Recording}

Sound files were digitally recorded in a sound-attenuated booth by two native speakers of U.S. English - one female (prime words) and one male (target words) - who were naive to the purpose of the experiment. The speakers were coached in pronouncing the words and nonwords correctly and in delivering all items clearly and with a consistent intonation, sound level, and speed. A pseudorandom recording order was created to ensure that no changes in speech over the course of the recording session would correlate with experimental factors.

Recordings were later filtered of white noise, edited into individual sound files, and further normalized for sound level. Analyses of sound file lengths confirmed that these were properly balanced (see Table 1).

\section{EEG Recording}

We recorded EEG using 26 electrodes embedded in an ElectroCap. These electrodes consisted of the 19 electrodes of the International 10-20 system (Jasper, 1958) plus 7 additional electrodes at positions AF3/4, FC5/6, CP5/6, and POz. Four external electrodes recorded the left mastoid, right mastoid, left-horizontal electrooculogram (EOG), and left-vertical EOG. EEG was recorded with reference to the left mastoid and was later re-referenced to the average of the two mastoids. Signals were amplified $(\times 20,000)$, filtered $(0.1-80 \mathrm{~Hz})$, and digitized at a sampling rate of $256 \mathrm{~Hz}$ (SA Instrumentation). Eyeblinks that were uncontaminated by additional artifacts were corrected using an adaptive filtering algorithm.

On the basis of visual inspection of the averaged data, mean amplitudes were calculated for prime words and target words across two time windows of 300-500 msec and 500-700 msec following word onset, in relation to a $100-\mathrm{msec}$ window preceding word onset. The 300 - to 500-msec window was chosen because it centered on the N400 negativity. It was clear that additional differences were emerging following $500 \mathrm{msec}$; thus, a second window of equal size, from 500 to $700 \mathrm{msec}$, was chosen to examine these later effects. No main effects of electrode are reported. Interactions involving electrode are reported with uncorrected $F$ values and degrees of freedom and with Greenhouse-Geisser-corrected $p$ values.

Topographic maps showing the distribution of the N400 effect for the target words were created by calculating voltage differences between the unprimed and primed conditions at each electrode and interpolating voltage differences for the rest of the scalp using a spherical spline mapping method (Perrin, Pernier, Bertrand, \& Echallier, 1989).

Table 1

Auditory Immediate-Priming Design With Lexical Decision

\begin{tabular}{|c|c|c|c|c|c|}
\hline Word Type & Priming & Prime & Target & $\begin{array}{l}\text { Target } \\
\text { Freq.* }\end{array}$ & $\begin{array}{l}\text { Target Length } \\
(\mathrm{msec})\end{array}$ \\
\hline \multirow{3}{*}{$\begin{array}{l}\text { Regular verbs } \\
\quad(n=150)\end{array}$} & Primed & looked & look & $1.94 \pm 0.4$ & $528 \pm 92$ \\
\hline & Unprimed & worked & seem & $1.94 \pm 0.4$ & $523 \pm 78$ \\
\hline & Nonword & asked & tarb & & \\
\hline \multirow{2}{*}{$\begin{array}{l}\text { Irregular verbs } \\
\quad(n=150)\end{array}$} & Primed & spoke & speak & $1.98 \pm 0.8$ & $515 \pm 92$ \\
\hline & $\begin{array}{l}\text { Unprimed } \\
\text { Nonword }\end{array}$ & $\begin{array}{l}\text { bound } \\
\text { took }\end{array}$ & $\begin{array}{l}\text { wake } \\
\text { *plinn }\end{array}$ & $1.98 \pm 0.8$ & $518 \pm 81$ \\
\hline \multirow{2}{*}{$\begin{array}{l}\text { Pseudopast } \\
\qquad(n=150)\end{array}$} & Primed & bead & bee & $1.61 \pm 1.1$ & $516 \pm 53$ \\
\hline & $\begin{array}{l}\text { Unprimed } \\
\text { Nonword }\end{array}$ & $\begin{array}{l}\text { bulb } \\
\text { deer }\end{array}$ & $\begin{array}{l}\text { pie } \\
{ }^{*} \text { cleeth }\end{array}$ & $1.59 \pm 1.1$ & $522 \pm 65$ \\
\hline \multirow{2}{*}{$\begin{array}{l}\text { Orthophono } \\
\qquad(n=150)\end{array}$} & Primed & barge & bar & $1.29 \pm 0.9$ & $494 \pm 70$ \\
\hline & Unprimed & bribe & tea & $1.21 \pm 0.8$ & $496 \pm 64$ \\
\hline
\end{tabular}

${ }^{* *} \log$ lemma frequency per million $\pm S D$. 


\section{RESULTS}

\section{Behavioral Data}

An ANOVA on the response times for correct lexical decisions revealed main effects of word type $[F(3,45)=$ $18.7, p<.001]$ and priming $[F(1,15)=25.4, p<.001]$. Participants tended to be faster overall in responding to the two verb conditions and slower for the two phonological conditions, independent of the priming manipulation. They were also faster in responding to primed words (Figure 1A). The interaction between word type and priming was not significant $[F(3,45)=1.9, p=.15]$. Nevertheless, we performed a series of planned comparisons, given that a major interest a priori was the relative sizes of the four priming effects. Significant positive priming was found for each of the four word types individually [regular, $73 \mathrm{msec}, t(15)=4.5, p<.001$; irregular, $91 \mathrm{msec}$, $t(15)=4.9, p<.001$; pseudopast, $47 \mathrm{msec}, t(15)=2.5$, $p=.03$; orthophono, $63 \mathrm{msec}, t(15)=3.6, p=.003$ ].

In a second analysis, we explored the effect of the degree of irregularity within the irregular word set (Figure 1B). Significant positive priming was observed for both the strong $[t(15)=5.1, p<.001]$ and the weak irregular $[t(15)=2.5, p=.02]$ verbs . Furthermore, comparisons of priming effect size demonstrated that there was significantly greater priming for strong verbs than for weak irregulars $[F(1,15)=7.1, p=.02]$.

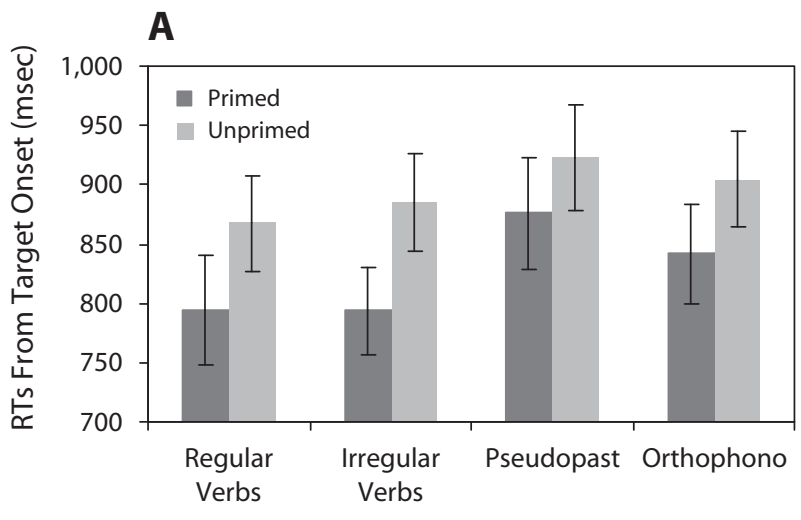

B

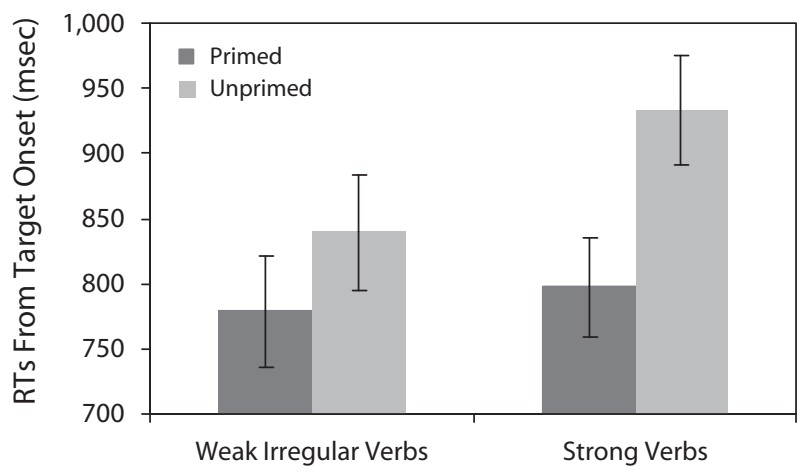

Figure 1. Behavioral data. Mean response times (RTs) for (A) correct lexical decisions as a function of word type and priming and (B) irregular verbs alone, separated into weak and strong. Error bars represent standard errors.
Comparisons of the mean priming effect sizes for regular verbs $(73 \mathrm{msec})$, weak irregular verbs $(60 \mathrm{msec})$, and strong verbs $(136 \mathrm{msec})$ suggest that the regular verbs may have primed more strongly than did the weak irregular verbs. However, this relies on a power-biased comparison of 50 potential observations per participant for the regular verbs and 23 potential observations for the weak irregulars, a comparison which, despite this bias, was not significant $[t(15)=.87, p=.40]$. In contrast, the priming effect for the 27 strong verbs was numerically larger than that of the 50 regular verbs, and, despite a bias in power favoring the reverse effect, was statistically significant $[t(15)=2.5, p=.03]$.

\section{ERP Data: Target Words}

Central-parietal region of interest (ROI). As preliminary analyses using two time windows (300-500 and 500-700 msec) over all 26 scalp electrodes revealed an N400 priming effect that was centered over central-posterior electrodes, we first chose a 9-electrode $\mathrm{ROI}(\mathrm{Cz} / \mathrm{Pz} / \mathrm{POz} /$ $\mathrm{C} 3 / \mathrm{C} 4 / \mathrm{CP} 5 / \mathrm{CP} 6 / \mathrm{P} 3 / \mathrm{P} 4)$ to examine the relative sizes and durations of the N400 effects across the four conditions (Figure 2). A pair of $4 \times 2 \times 9$ ANOVAs were performed using the variables of word type, priming, and electrode for this ROI - one for each time window.

During the $300-$ to $500-\mathrm{msec}$ window, there was no main effect of word type $(p=.28)$, but there was a robust effect of priming $[F(1,15)=52.4, p<.001]$ and a trend toward an interaction between these variables $[F(3,45)=$ $2.4, p=.08]$. Significant N400 reductions were observed for each of the four word types individually [regular, $F(1,15)=27.8, p<.001$; irregular, $F(1,15)=29.3, p<$ .001 ; pseudopast, $F(1,15)=4.5, p=.05$; orthophono, $F(1,15)=17.6, p=.001]$. Planned comparisons revealed that regular and irregular priming effects were statistically indistinguishable during this time window $(p=.91)$. However, both verb classes reliably primed more strongly than did each semantically unrelated control, and the orthophono condition primed more strongly than did the pseudopast condition (five interactions, each $p<.001$ ).

In an analysis that divided irregulars into strong and weak irregular verbs (Figure 3), a highly significant priming effect was found for both [strong, $F(1,15)=13.5, p=.002$; weak, $F(1,15)=24.0, p<.001]$. These two effects were not distinguishable between 300 and $500 \mathrm{msec}(p=.88)$.

During the later 500- to $700-\mathrm{msec}$ window, there were significant effects of word type $[F(3,45)=11.6, p<.001]$ and priming $[F(1,15)=22.3, p<.001]$. There was also a significant word type $\times$ priming interaction $[F(3,45)=$ $5.6, p=.002]$. Significant positive priming was observed for regulars $[F(1,15)=13.8, p=.002]$ and irregulars $[F(1,15)=23.7, p<.001]$, but not for the pseudopast $(p=.81)$ or orthophono $(p=.23)$ conditions. In contrast with that during the earlier 300- to 500-msec window, the priming effect during the 500- to $700-\mathrm{msec}$ window was significantly larger for the irregular than for the regular verbs $[F(1,15)=25.1, p<.001]$. Further planned comparisons revealed that the irregular effect was larger than both the pseudopast $[F(1,15)=17.3, p=.001]$ and orthophono $[F(1,15)=6.8, p=.02]$ effects, the regular effect was 


\section{Regular Verbs} (looked-look)
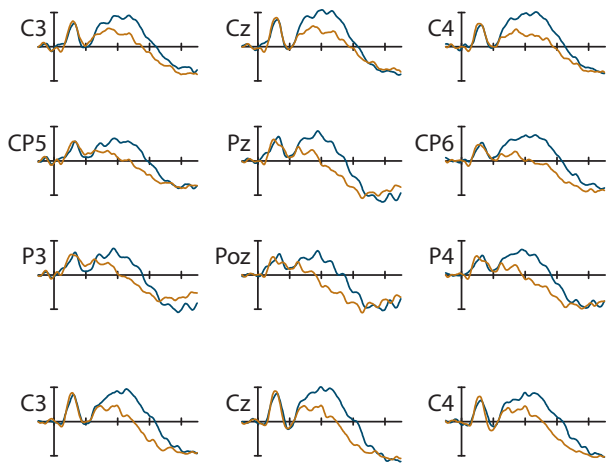

Irregular Verbs (combined) (spent-spend; spoke-speak)
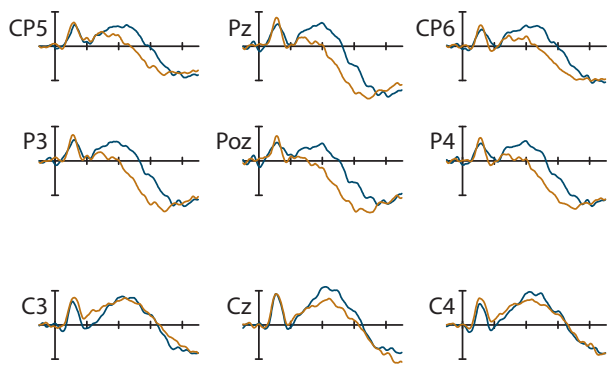

Pseudopast (bead-bee)
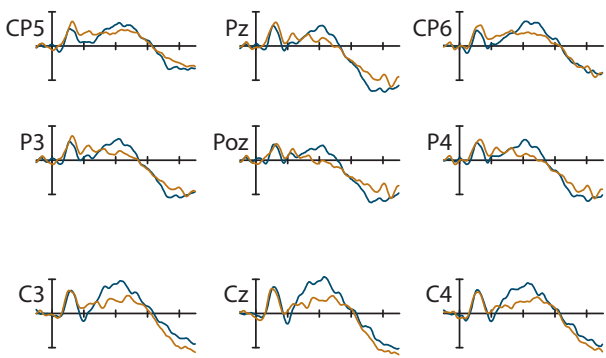

Orthophono
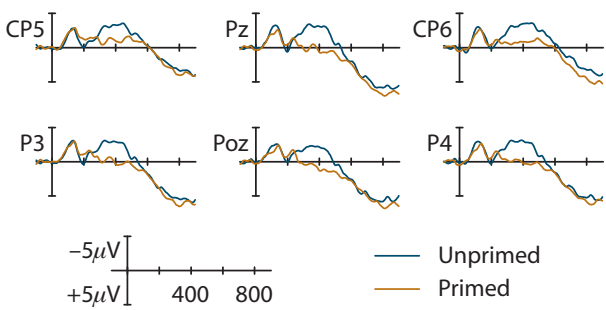

Figure 2. ERPs to target words within the nine-electrode region of interest, demonstrating the $\mathbf{N} 400$ effect and its reduction for each of the four word types: regular verbs, irregular verbs, pseudopast, and orthophono.

larger than the pseudopast effect $[F(1,15)=6.1, p=.03]$ and (marginally) the orthophono effect $[F(1,15)=2.9$, $p=.11]$; the pseudopast and orthophono conditions did not significantly differ from each other $(p=.56)$.

When comparing the strong and weak irregular verbs during this window, we found significant priming for both [strong, $F(1,15)=26.8, p<.001$; weak, $F(1,15)=$ $7.1, p=.02]$. Furthermore, there was greater priming for strong than for weak irregular verbs $[F(1,15)=6.9, p=$ $.02]$. The difference between the irregulars as a group in comparison with the regulars seems to have been driven primarily by the strong verbs: The priming effect for the strong verbs was significantly larger than that for the regu- lar verbs $[F(1,15)=7.1, p=.02]$, but the priming effect for the weak irregular verbs was not $(p=.87)$.

Scalp distributions. The ROI analysis just described limited the data to the central parietal electrodes in which the N400 is most readily observed. This was done to maximize sensitivity for the detection of differences in the amplitude of the N400 priming effect as a function of word type. This approach may result in a failure to observe differences in the scalp distribution of the effect across word types. Therefore, the priming effect sizes at all scalp electrodes were used to generate topographic maps at both the 300- to 500-msec and 500- to 700-msec windows for the four word types (Figure 4A) and the weak irregular/ 


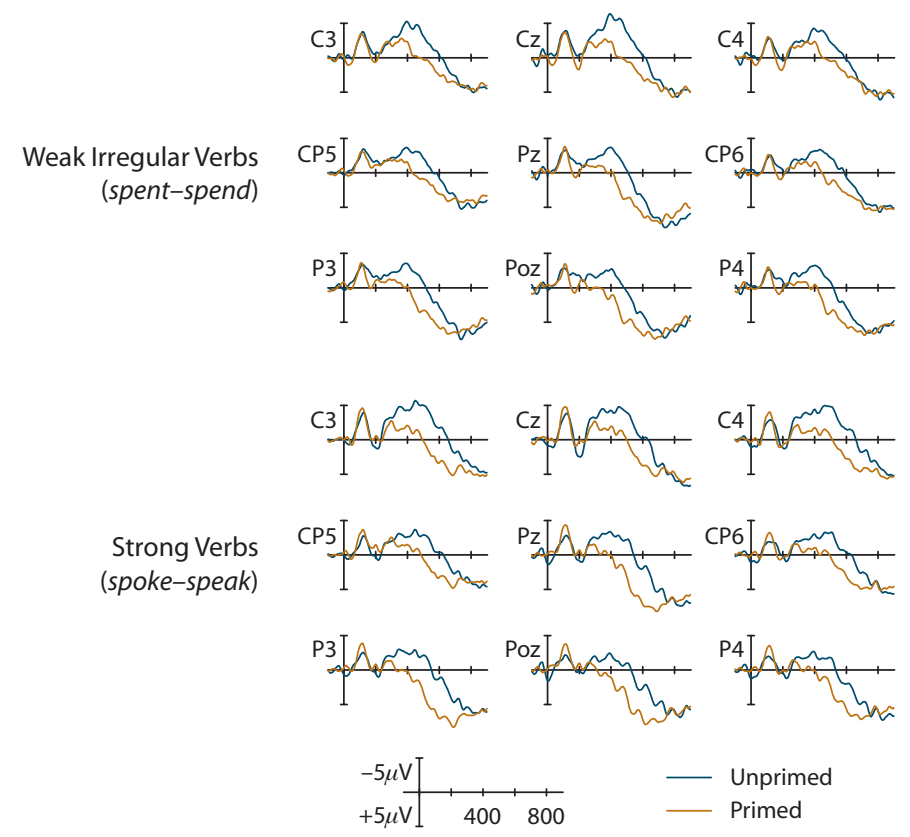

Figure 3. ERPs to target words within the nine-electrode region of interest, demonstrating the $\mathrm{N400}$ effect and its reduction for the irregular verbs specifically, divided into weak irregular verbs and strong verbs.

strong verb split (Figure 4B). These figures first provide another visualization of the prolonged priming effect for irregular verbs and of the dependence of this effect on the strong verbs specifically.

The figures also suggest that the topography of the N400 priming effect differed across the conditions. To fully explore this possibility, we performed a final pair of analyses using 16 electrodes grouped into four quadrants (anterior left, FP1/F3/F7/FC5; anterior right, FP2/F4/F8/ FC6; posterior left, O1/P3/T5/CP5; posterior right, O2/ P4/T6/CP6). We conducted a final pair of $4 \times 2 \times 2 \times 2$ ANOVAs for the two time windows with word type, priming, anterior/posterior, and left/right as factors.

The only interactions involving the latter two variables were one between priming and anterior/posterior for the early window $[F(1,15)=37.9, p<.001]$, confirming that the N400 priming effect was larger for the posterior electrodes, and a trend toward an interaction between priming and left/right, also during the early window $[F(1,15)=$ $3.4, p=.086]$, suggesting a slightly larger priming effect over the left hemisphere. No interactions between these variables and word type were observed (all $p \mathrm{~s}>.20$ ), indicating that the topography of the N400 priming effect did not differ significantly across word type.

\section{ERP Data: Prime Words}

We also conducted an analysis of the ERPs to the prime words. These ERPs were expected to be similar to each other, given the design of the stimuli, and, if anything, to differ subtly according to necessary differences in word frequency and part of speech. Although the frequencies for the regular and irregular verbs were nearly perfectly balanced (mean log lemma frequency per million of 1.94 and 1.98 , respectively), the pseudopast and orthophono primes had slightly lower frequencies (1.22 and 1.06, respectively). In contrast to the two verb conditions, the pseudopast and orthophono stimuli consisted mostly of nouns, followed by verbs, adjectives, adverbs, and a few closed-class words, all balanced between primed and unprimed items. N400 amplitude tends to be larger for low-frequency words (Rugg, 1990) and larger for nouns than verbs (Federmeier, Segal, Lombrozo, \& Kutas, 2000; Khader, Scherag, Streb, \& Rösler, 2003).

As with the target words, the presentation of the primes also elicited N400s that were centered over centralposterior electrodes, and we chose the same 9-electrode ROI (Figure 5). A pair of $4 \times 9$ ANOVAs were performed using the variables word type and electrode, one for each of the 300- to 500-msec and 500- to 700-msec windows. The data were collapsed across the priming variable for this analysis because no systematic differences existed across this variable for the prime words (see the Appendix).

During the 300- to 500-msec window, there was a main effect of word type $[F(3,45)=3.1, p=.03]$. Six post hoc comparisons among the four word types revealed that the ERP to the pseudopast words was significantly more negative than that to either the regular $[F(1,15)=6.4, p=.02]$ or orthophono $[F(1,15)=6.7, p=.02]$ conditions. The other four comparisons were not significant $(p>.15)$.

During the 500- to $700-\mathrm{msec}$ window, there was also a main effect of word type $[F(3,45)=5.6, p=.002]$. Post hoc comparisons revealed that the ERPs to the pseudopast and orthophono words were each significantly more negative than those to the regular and irregular verbs $[\mathrm{P}<\mathrm{R}, F(1,15)=10.9, p=.005 ; \mathrm{O}<\mathrm{R}, F(1,15)=9.4$, $p=.008 ; \mathrm{P}<\mathrm{I}, F(1,15)=6.3, p=.02 ; \mathrm{O}<\mathrm{I}, F(1,15)=$ 
A Regular Verbs (looked-look)
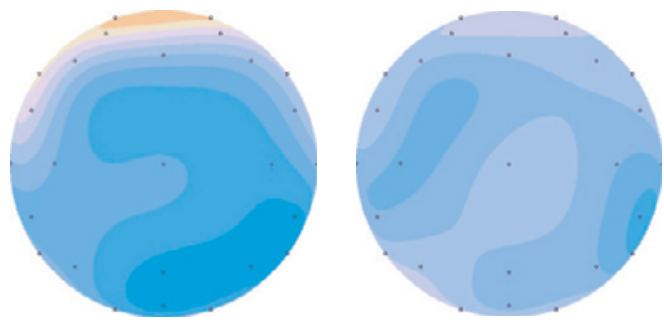

Irregular Verbs (spent-spend; spoke-speak)
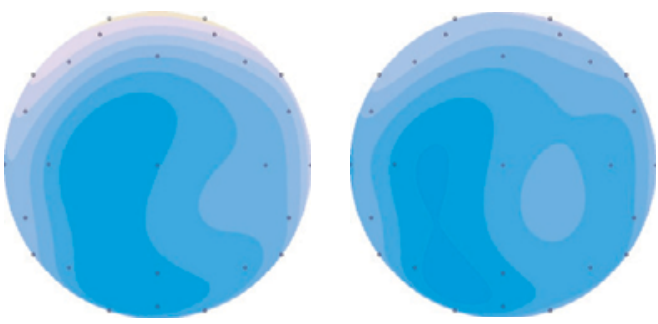

Pseudopast (bead-bee)
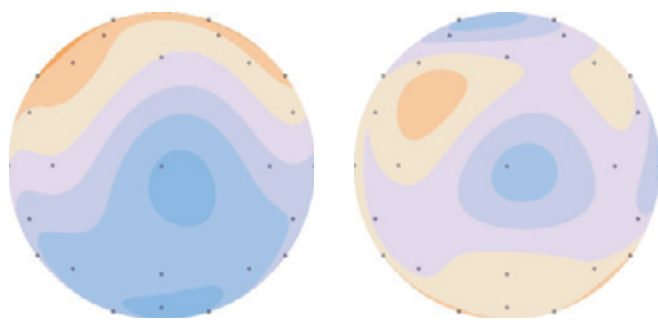

Orthophono (barge-bar)

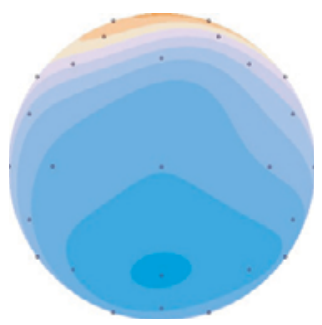

$300-500 \mathrm{msec}$

\section{B Weak Irregular Verbs (spent-spend)}
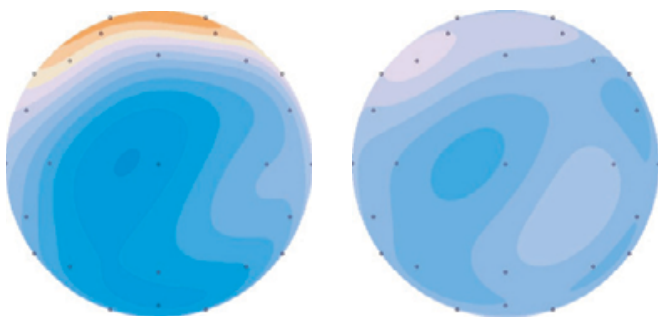

Strong Verbs (spoke-speak)

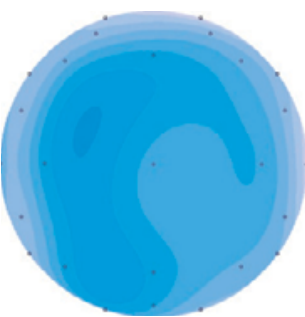

$300-500 \mathrm{msec}$

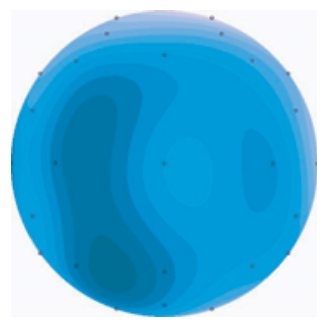

$500-700 \mathrm{msec}$
Primed $<$ Unprimed $\begin{array}{llllllll}-1 & 0 & 1 & 2 & 3 & 4 & 5 & 6\end{array}$

Difference $(\mu \mathrm{V})$
Unprimed $<$

Primed

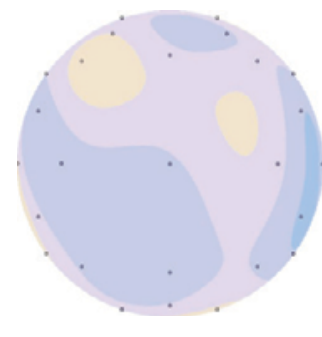

$500-700 \mathrm{msec}$

Figure 4. Topographic maps of the scalp distributions displaying the N400 priming effect for target words (difference between primed and unprimed waveforms) between 300-500 and 500-700 msec for (A) each of the four word types: regular verbs, irregular verbs, pseudopast, and orthophono and (B) weak irregular verbs and strong verbs.

$5.1, p=.04]$. The regular-irregular and pseudopastorthophono comparisons were not significant $(p>.40)$.

\section{DISCUSSION}

\section{Similarities and Differences Between Regular and Irregular Effects}

Both regular and irregular past-tense forms serve as effective primes for corresponding present-tense forms in healthy participants in the immediate-priming design.
Additionally, both forms of priming are associated with a reduction in the N400 component over central-parietal electrodes. This reduction was of a longer duration for irregular forms, lasting well into the later 500- to 700-msec window.

Although the longer N400 reduction was not associated with a significantly larger behavioral effect for the irregular verbs, there was a trend in this direction $(73 \mathrm{msec}$ for regulars; $91 \mathrm{msec}$ for irregulars). A reconsideration of previously reported priming data suggests that stron- 
ger priming is consistently found for irregular verbs than for regular verbs in healthy control groups (Longworth, Keenan, et al., 2005; Marslen-Wilson \& Tyler, 1997; Tyler, de Mornay Davies, et al., 2002; Tyler et al., 2004), although a significant interaction between priming and regularity is only observable in some of these cases. Before considering the reason underlying these differences, we note that caution should be used when interpreting the performance of patients with significant priming for irregulars and not for regulars (as is sometimes the case with anterior aphasics), given that the former is simply a more robust effect.

The formal priming effects (phonological and orthographic) that we observed in this experiment do not explain the regular-irregular difference. Positive formal priming would predict a larger effect for the regulars, but not for the irregulars, as we observed. Also, the time courses of the effects were different: Whereas the priming effect for the two verb conditions was observed across both windows (300-700 msec), the formal effects were limited to the early window $(300-500 \mathrm{msec})$, and the regular-irregular difference was limited to the late window (500-700 msec).

The longer duration of priming for irregular than for regular verbs could be due to a difference in morphological processing per se. However, we are unaware of any proposed morphological mechanism that predicts a greater extent of priming for the irregular verbs in the immediate-priming design. In particular, morphological
Regular Verb Primes (looked)
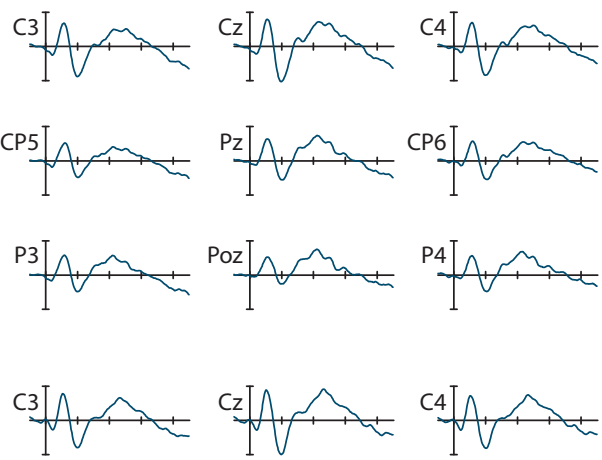

Irregular Verb Primes (spent; spoke)
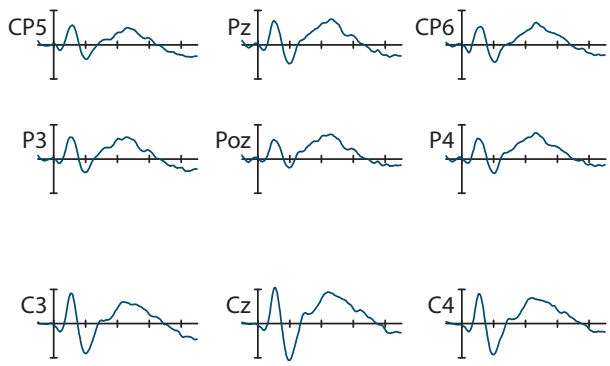

Pseudopast Primes

(bead)
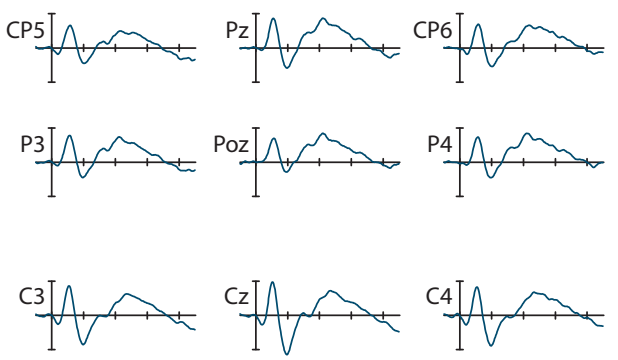

Orthophono Primes (barge)
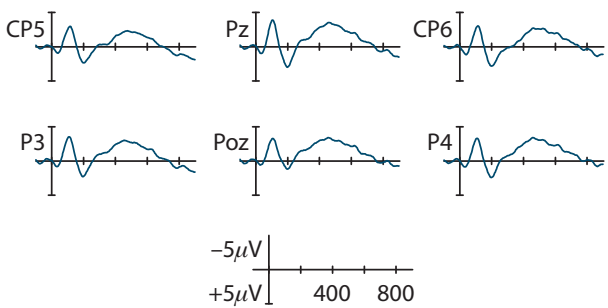

Figure 5. ERPs to prime words within the nine-electrode region of interest, demonstrating the $\mathrm{N} 400$ effect for each of the four word types: regular verbs, irregular verbs, pseudopast, and orthophono. 
priming does not easily explain the observation that the strong verbs in particular - and not all irregular formsdrove this regular-irregular difference.

Given this observation, we suggest that greater semantic priming occurs between irregular past- and present-tense forms than between regular past- and present-tense forms. This suggestion is consistent with the reliance of irregular morphology on semantic representations posited by some single-system theories (e.g., Joanisse \& Seidenberg, 1999), but may be problematic for at least some variants of the dual-system approach. In the remainder of this Discussion, we further consider the nature of the link between irregular morphology and semantics, return to the phonological and orthographic effects, and finally discuss the comparison of regular, weak irregular, and strong verbs.

\section{Irregular Morphology and Semantics}

The relationship between irregular morphology and semantic representations is currently under much debate, given the prediction of single-system theories that irregular verbs may be more dependent on semantic representations than are regular verbs (Joanisse \& Seidenberg, 1999; McClelland \& Patterson, 2002). Both dual- and single-system theorists acknowledge that deficits in both irregular morphology and semantics are often associated with more posterior aphasias affecting the temporal lobe. The main point of disagreement is whether deficits in irregular morphology and semantics simply co-occur as the result of large brain lesions that are likely to damage neighboring, but independent, modules (Miozzo, 2003) or whether deficits in irregular morphology arise directly from compromised semantic representations (Patterson et al., 2001).

The dual-system "words and rules" theory (Pinker, 1999), while arguing that irregular past-tense verbs are stored in the mental lexicon as fully listed words, makes a distinction between the mental lexicon and semantic representations, suggesting that they are separate modules and are not tightly linked. This is based in part on behavioral evidence suggesting that semantic information does not play a role in the generation of past tenses (Kim, Pinker, Prince, \& Prasada, 1991; cf. Ramscar, 2002). Also, neuropsychological evidence suggests that irregular morphology and semantics can dissociate following brain damage (Miozzo, 2003; Miozzo \& Gordon, 2005; Tyler et al., 2004).

Another dual-system theory, the declarative/procedural model (Ullman, 2001, 2004), may be more amenable to a deeper connection between irregular morphology and semantics. According to the declarative/procedural model, irregular morphology depends on temporal lobe structures that underlie "declarative" memory, including both episodic and semantic memory. While maintaining a clear distinction between regular and irregular morphology like other dual-system theories, the declarative/ procedural model suggests that the mental lexicon (and irregular morphology) may be grounded in the semantic representations of declarative memory.

The single-system perspective most easily integrates our suggestion of greater semantic facilitation between irregular past- and present-tense forms than between regular pastand present-tense forms, because this approach has specifi- cally predicted such a difference (Joanisse \& Seidenberg, 1999). Stronger semantic links between irregular past- and present-tense forms may result from the less predictable phonological relationship between the two, in contrast with the perfectly predictable phonological relationship between regular past- and present-tense forms. Indeed, recent analyses of lexical statistics suggest that irregular verbs may cluster more densely in semantic space (Baayen \& Moscoso del Prado Martín, 2005), which suggests that semantics may play a much stronger role in determining verb inflection than was previously believed.

\section{Phonological and Orthographic Effects}

Primes and targets that are related only in terms of phonological and orthographic overlap do prime one another behaviorally in this design. This contrasts with previously reported results that have tested for such effects with less power (Longworth, Keenan, et al., 2005; Tyler, de Mornay Davies, et al., 2002; Tyler et al., 2004). Such priming is also associated with a reduction of the N400 component, as has been shown previously (Praamstra, Meyer, \& Levelt, 1994), although other studies have suggested that a unique component reflecting phonological mismatch precedes the N400 (e.g., Connolly \& Phillips, 1994). These effects are much smaller and shorter lived than those of the semantically and morphologically related verb tense conditions (see also Doyle, Rugg, \& Wells, 1996) and do not in isolation account for the difference between the regular and irregular verbs. The observation of this effect may prove useful in future studies testing for the relationship between deficits in regular morphology and phonological processing.

Larger N400 priming was observed during the orthophono condition than during the pseudopast condition. Both of these conditions contained phonological overlap, but they differed in two ways. The first difference was that the pseudopast condition was constructed in such a way that prime and target differed only by the removal of a dental stop consonant (e.g., bead-bee), whereas the orthophono condition differed by the removal of other consonants (e.g., barge-bar). The second difference between the two was that, by necessity, most pseudopast pairs included spelling changes, and this resulted in greater orthographic overlap for the orthophono condition. We suggest that this is the reason for the N400 difference between the two, despite the fact that all stimuli were spoken and not written. Such a result is consistent with previous work suggesting access to orthographic codes during speech perception (Miller \& Swick, 2003).

\section{Comparison of Regular, Weak Irregular, and Strong Verbs}

The most intriguing result of the present study resulted from the division of the irregular verb set into two halves corresponding to strong verbs (e.g., spoke-speak) and weak irregular verbs (e.g., spent-spend). The past-tense forms of weak irregular and strong verbs were shown to prime their present-tense forms. Furthermore, the N400 and response-time priming effects for the strong verbs were stronger than those for the weak irregular verbs and for the regular verbs (e.g., looked-look). This suggests that the regular-irregular difference in this experimental 
design is primarily driven by the inclusion of strong verbs in the irregular set.

The dual-system model does not easily incorporate a dissociation between weak irregular and strong verbs, nor does it incorporate a regular-irregular dissociation that is driven by strong verbs specifically. In all versions of the model that have been articulated, a categorical distinction is maintained between regular and irregular verbs: Either a verb conforms to the regular/d/ pattern, and its past tense is generative, or the verb is an exception, and its past tense is represented lexically.

One might attempt to incorporate the present results within the dual-system model by arguing for morphological decomposition of all weak verbs - including weak irregulars - and full listing of only the strong verbs in the lexicon. However, this is a rather nonparsimonious solution that eliminates all of the advantages of the dualsystem model. Instead of a model with a single rule (with three perfectly predictable /d/ allomorphs) accounting for all regular verbs, and a myriad of exceptions encoded in the lexicon for all irregulars, a weak-strong dual-system model would result in both a myriad of rules to cover pasttense formation for all of the weak verbs (including regulars and weak irregulars) and individual lexical encoding of all of the remaining strong exceptions.

Our results partly, but not completely, conform to the predictions of single-system approaches arguing that regular, weak irregular, and strong verbs fall on a continuum of dependence on phonological and semantic representations. In the model of Joanisse and Seidenberg (1999), regular and irregular verbs differ in their dependence on phonological and semantic representations in mapping the relationship between the present- and past-tense forms. One might argue that the predictability in phonological mapping between present- and past-tense forms for a weak irregular verb falls between that of a regular verb (very high in predictability) and a strong verb (lower in predictability). If this is true, the model of Joanisse and Seidenberg (1999) would predict that dependence of a weak irregular verb on semantic representations for linking present- and past-tense forms should be greater than that of a regular verb (less dependent on semantics), but less than that of a strong verb (highly dependent on semantics). If so, this would suggest that priming effects for weak irregular verbs should be intermediate in size and duration in comparison with those for regular and strong verbs.

The present study provides support for half of this prediction, documenting the greater behavioral and N400 priming for strong verbs than for weak irregulars, but not for weak irregulars in comparison with regulars, which were statistically equivalent. One possible explanation for the latter is our choice in experimental design - having equal numbers of regular and irregular verbs in the study, rather than having equal numbers of regular, weak irregular, and strong verbs. The power bias after splitting the irregulars into weak irregular and strong may not have permitted the observance of differences between an effect that the single-system model predicts to be smaller, but is observed with greater power (the regulars), and an effect that the model predicts to be larger, but is observed with less power (the weak irregulars). Alternatively, the null result suggested by this comparison may simply reflect a lack of systematic differences between regular and weak irregular priming effects in this design.

The continuum argument may be an oversimplification of the differences between the weak irregulars and the strong verbs in terms of their phonological properties. Although the weak irregulars end in a dental stop consonant in the past tense, just as the regulars do, this does not mean that the past tense of weak irregular verbs is more phonologically predictable than are the past tenses of strong verbs. In fact, the strong verbs, with clear family resemblances in present-past mapping, have historically drawn in new members from the weak verb classes. Examples of this include the verbs wear and ring, which previously followed a (pre-regular) weak pattern (Hare \& Elman, 1995), and, more recently, the verb sneak, whose strong irregular past snuck began to replace the regular form sneaked in some U.S. English dialects in the 19th century (Pinker, 1999). These historical observations parallel psycholinguistic patterns, including the errors that children and adults make when performing past-tense generation tasks (Bybee \& Slobin, 1982). To our knowledge, the relative degrees of phonological regularity between (and within) the classes of weak irregular and strong verbs is an open empirical question that will be informed by both diachronic and synchronic data.

Nevertheless, the present study advances a new empirical observation that must be accounted for by any complete model of the English past tense - a significant behavioral and electrophysiological difference between the processing of weak irregular verbs and strong verbs. Most empirical studies of the past tense have not examined how the large heterogeneity within the irregular class may contribute to dissociations between regular and irregular verbs (but see Bird et al., 2003; Joanisse \& Seidenberg, 2005; Patterson et al., 2001). Such finer distinctions within the irregular class will prove critical in determining the most appropriate characterization of English past-tense formation.

\section{AU'THOR NOTE}

This research was supported by NIH Grant P01NS40813. Some of these data were previously presented at the 2005 meetings of the Cognitive Neuroscience Society in New York and the Academy of Aphasia in Amsterdam. For their assistance with various stages of this project, we thank Jennifer Yang, Doug Mobley, Randi Johnsen, Adrian Willoughby, David Wilkins, and Alex Hurst. Correspondence concerning this article should be addressed to T. Justus, Cognitive Neuropsychology \& Electrophysiology Laboratory, VA Northern California Health Care System, 150 Muir Road, Research Building 4, Martinez, CA 94553-4668 (e-mail: tjustus@ebire.org).

Note-This article was accepted by the previous editorial team, when John Jonides was Editor.

\section{REFERENCES}

Batyen, R. H., \& Moscoso del Prado Martín, F. (2005). Semantic density and past-tense formation in three Germanic languages. Language, 81, 666-698.

BaAyen, R. H., Piepenbrock, R., \& Gulikers, L. (1995). The CELEX lexical database (Release 2) [CD-ROM]. Philadelphia, PA: Linguistic Data Consortium, University of Pennsylvania [Distributor].

Bartke, S., Rösler, F., Streb, J., \& Wiese, R. (2005). An ERP-study 
of German "irregular" morphology. Journal of Neurolinguistics, 18, 29-55.

Becker, S., Moscovitch, M., Behrmann, M., \& Joordens, S. (1997). Long-term semantic priming: A computational account and empirical evidence. Journal of Experimental Psychology: Learning, Memory, \& Cognition, 23, 1059-1082.

Bentin, S., \& Peled, B.-S. (1990). The contribution of task-related factors to ERP repetition effects at short and long lags. Memory \& Cognition, 18, 359-366.

Beretta, A., Campbell, C., Carr, T. H., Huang, J., Schmitt, L. M., Christianson, K., \& CAO, Y. (2003). An ER-fMRI investigation of morphological inflection in German reveals that the brain makes a distinction between regular and irregular forms. Brain \& Language, 85, 67-92.

Bird, H., Lambon Ralph, M. A., Seidenberg, M. S., McClelland, J. L., \& PAtTerson, K. (2003). Deficits in phonology and past-tense morphology: What's the connection? Journal of Memory \& Language, 48, 502-526.

Braber, N., Patterson, K., Ellis, K., \& Lambon Ralph, M. A. (2005). The relationship between phonological and morphological deficits in Broca's aphasia: Further evidence from errors in verb inflection. Brain \& Language, 92, 278-287.

BRown, R. (1973). A first language: The early stages. Cambridge, MA: Harvard University Press.

Bybee, J. L., \& Slobin, D. I. (1982). Rules and schemas in the development and use of the English past tense. Language, 58, 265-289.

Clahsen, H. (1999). Lexical entries and rules of language: A multidisciplinary study of German inflection. Behavioral \& Brain Sciences, 22, 991-1013.

Connolly, J. F., \& Phillips, N. A. (1994). Event-related potential components reflect phonological and semantic processing of the terminal word of spoken sentences. Journal of Cognitive Neuroscience, 6, 256-266.

de Diego Balaguer, R., Rodríguez-Fornells, A., Rotte, M., BahlmanN, J., HeInZE, H.-J., \& Münte, T. F. (2006). Neural circuits subserving the retrieval of stems and grammatical features in regular and irregular verbs. Human Brain Mapping, 27, 874-888.

de Diego Balaguer, R., Sebastián-Gallés, N., Díaz, B., \& RoDRíGUEZ-ForNELLS, A. (2005). Morphological processing in early bilinguals: An ERP study of regular and irregular verb processing. Cognitive Brain Research, 25, 312-327.

Doyle, M. C., RugG, M. D., \& Wells, T. (1996). A comparison of the electrophysiological effects of formal and repetition priming. Psychophysiology, 33, 132-147.

Elman, J. L., Bates, E. A., Johnson, M. H., Karmiloff-Smith, A., Parisi, D., \& Plunkett, K. (1996). Rethinking innateness: A connectionist perspective on development. Cambridge, MA: MIT Press.

Federmeier, K. D., Segal, J. B., Lombrozo, T., \& Kutas, M. (2000). Brain responses to nouns, verbs and class-ambiguous words in context. Brain, 123, 2552-2566.

Feustel, T. C., Shiffrin, R. M., \& Salasoo, A. (1983). Episodic and lexical contributions to the repetition effect in word identification. Journal of Experimental Psychology: General, 112, 309-346.

Fowler, C. A., Napps, S. E., \& Feldman, L. (1985). Relations among regular and irregular morphologically related words in the lexicon as revealed by repetition priming. Memory \& Cognition, 13, 241-255.

Gross, M., Say, T., Kleingers, M., Clahsen, H., \& Münte, T. F. (1998). Human brain potentials to violations in morphologically complex Italian words. Neuroscience Letters, 241, 83-86.

Hanson, V. L., \& Wilkenfeld, D. (1985). Morphophonology and lexical organization in deaf readers. Language \& Speech, 28, 269-280.

HARE, M., \& ElMAN, J. L. (1995). Learning and morphological change. Cognition, 56, 61-98.

JAEger, J. J., LockwoOd, A. H., Kemmerer, D. L., VAN VAlin, R. D., JR., Murphy, B. W., \& KhalaK, H. G. (1996). A positron emission tomographic study of regular and irregular verb morphology in English. Language, 72, 451-497.

JASPER, H. H. (1958). The ten twenty electrode system of the International Federation. Electroencephalography \& Clinical Neurophysiology, 10, 371-375.

JoAnisse, M. F., \& Seidenberg, M. S. (1999). Impairments in verb morphology after brain injury: A connectionist model. Proceedings of the National Academy of Sciences, 96, 7592-7597.
JoAnisse, M. F., \& Seidenberg, M. S. (2005). Imaging the past: Neural activation in frontal and temporal regions during regular and irregular past-tense processing. Cognitive, Affective, \& Behavioral Neuroscience, 5, 282-296.

JoOrdens, S., \& BECKER, S. (1997). The long and short of semantic priming effects in lexical decision. Journal of Experimental Psychology: Learning, Memory, \& Cognition, 23, 1083-1105.

Kempley, S. T., \& Morton, J. (1982). The effects of priming with regularly and irregularly related words in auditory word recognition. British Journal of Psychology, 73, 441-454.

Khader, P., Scherag, A., Streb, J., \& Rösler, F. (2003). Differences between noun and verb processing in a minimal phrase context: A semantic priming study using event-related brain potentials. Cognitive Brain Research, 17, 293-313.

Kim, J. J., Pinker, S., Prince, A., \& Prasada, S. (1991). Why no mere mortal has ever flown out to center field. Cognitive Science, 15, 173-218.

KuCZAJ, S. A., II (1977). The acquisition of regular and irregular past tense forms. Journal of Verbal Learning \& Verbal Behavior, 16, 589-600.

Kutas, M., \& Federmeier, K. D. (2000). Electrophysiology reveals semantic memory use in language comprehension. Trends in Cognitive Sciences, 4, 463-470.

Kutas, M., \& Hillyard, S. A. (1980). Reading senseless sentences: Brain potentials reflect semantic incongruity. Science, 207, 203-204.

Lambon Ralph, M. A., Braber, N., McClelland, J. L., \& PatterSON, K. (2005). What underlies the neuropsychological pattern of irregular $>$ regular past-tense verb production? Brain \& Language, 93, 106-119.

Longworth, C. E., Keenan, S. E., Barker, R. A., Marslen-Wilson, W. D., \& TYler, L. K. (2005). The basal ganglia and rule-governed language use: Evidence from vascular and degenerative conditions. Brain, 128, 584-596.

Longworth, C. E., Marslen-Wilson, W. D., Randall, B., \& Tyler, L. K. (2005). Getting to the meaning of the regular past tense: Evidence from neuropsychology. Journal of Cognitive Neuroscience, 17, 1087-1097.

MARcus, G. F. (2001). The algebraic mind: Integrating connectionism and cognitive science. Cambridge, MA: MIT Press.

Marslen-Wilson, W. D., \& Tyler, L. K. (1997). Dissociating types of mental computation. Nature, 387, 592-594.

McClelland, J. L., \& Patterson, K. (2002). Rules or connections in past-tense inflections: What does the evidence rule out? Trends in Cognitive Sciences, 6, 465-472.

Miller, K. M., \& Swick, D. (2003). Orthography influences the perception of speech in alexic patients. Journal of Cognitive Neuroscience, 15, 981-990.

Miozzo, M. (2003). On the processing of regular and irregular forms of verbs and nouns: Evidence from neuropsychology. Cognition, 87, 101-127.

Miozzo, M., \& Gordon, P. (2005). Facts, events, and inflection: When language and memory dissociate. Journal of Cognitive Neuroscience, 17, 1074-1086.

Morris, J., \& Holcomb, P. J. (2005). Event-related potentials to violations of inflectional verb morphology in English. Cognitive Brain Research, 25, 963-981.

Münte, T. F., Say, T., Clahsen, H., Schiltz, K., \& Kutas, M. (1999). Decomposition of morphologically complex words in English: Evidence from event-related brain potentials. Cognitive Brain Research, 7, 241-253.

NAGY, M. E., \& RugG, M. D. (1989). Modulation of event-related potentials by word repetition: The effects of inter-item lag. Psychophysiology, 26, 431-436.

NAPPS, S. E. (1989). Morphemic relationships in the lexicon: Are they distinct from semantic and formal relationships? Memory \& Cognition, 17, 729-739.

Patterson, K., Lambon Ralph, M. A., Hodges, J. R., \& McClelLAND, J. L. (2001). Deficits in irregular past-tense verb morphology associated with degraded semantic knowledge. Neuropsychologia, 39, 709-724.

Penke, M., Weyerts, H., Gross, M., Zander, E., Münte, T. F., \& Clahsen, H. (1997). How the brain processes complex words: An event-related potential study of German verb inflections. Cognitive Brain Research, 6, 37-52. 
Perrin, F., Pernier, J., Bertrand, O., \& Echallier, J. F. (1989). Spherical splines for scalp potential and current density mapping. Electroencephalography \& Clinical Neurophysiology, 72, 184-187.

Pinker, S. (1999). Words and rules: The ingredients of language. New York: Basic.

Pinker, S., \& Ullman, M. T. (2002). The past and future of the past tense. Trends in Cognitive Sciences, 6, 456-463.

Plunkett, K., \& Bandelow, S. (2006). Stochastic approaches to understanding dissociations in inflectional morphology. Brain \& Language, 98, 194-209.

Praamstra, P., Meyer, A. S., \& Levelt, W. J. M. (1994). Neurophysiological manifestations of phonological processing: Latency variation of a negative ERP component timelocked to phonological mismatch. Journal of Cognitive Neuroscience, 6, 204-219.

RAMSCAR, M. (2002). The role of meaning in inflection: Why the past tense does not require a rule. Cognitive Psychology, 45, 45-94.

Rastle, K., Harrington, J., \& Coltheart, M. (2002). 358,534 nonwords: The ARC nonword database. Quarterly Journal of Experimental Psychology, 55A, 1339-1362.

Rodríguez-Fornells, A., Clahsen, H., Lleó, C., ZaAke, W., \& MüNTE, T. F. (2001). Event-related brain responses to morphological violations in Catalan. Cognitive Brain Research, 11, 47-58.

Rodríguez-Fornells, A., Münte, T. F., \& Clahsen, H. (2002). Morphological priming in Spanish verb forms: An ERP repetition priming study. Journal of Cognitive Neuroscience, 14, 443-454.

RUGG, M. D. (1990). Event-related brain potentials dissociate repetition effects of high- and low-frequency words. Memory \& Cognition, 18, 367-379.

Rumelhart, D. E., \& McClelland, J. L. (1986). On learning the past tenses of English verbs. In J. L. McClelland, D. E. Rumelhart, \& the PDP Research Group (Eds.), Parallel distributed processing: Vol. 2. Psychological and biological models (pp. 216-271). Cambridge, MA: MIT Press.

Sahin, N. T., Pinker, S., \& Halgren, E. (2006). Abstract grammatical processing of nouns and verbs in Broca's area: Evidence from fMRI. Cortex, 42, 540-562.

Sonnenstuhl, I., Eisenbeiss, S., \& Clahsen, H. (1999). Morphological priming in the German mental lexicon. Cognition, 72, 203-236.

Stanners, R. F., Neiser, J. J., Hernon, W. P., \& Hall, R. (1979). Memory representation for morphologically related words. Journal of Verbal Learning \& Verbal Behavior, 18, 399-412.

Stolz, J. A., \& BeSNER, D. (1998). Levels of representation in visual word recognition: A dissociation between morphological and semantic processing. Journal of Experimental Psychology: Human Perception \& Performance, 24, 1642-1655.

Tyler, L. K., DeMornay-Davies, P., ANokhina, R., Longworth, C. [E.], Randall, B., \& MARSLEN-Wilson, W. D. (2002). Dissociations in pro- cessing past tense morphology: Neuropathology and behavioral studies. Journal of Cognitive Neuroscience, 14, 79-94.

Tyler, L. K., Randall, B., \& Marslen-Wilson, W. D. (2002). Phonology and neuropsychology of the English past tense. Neuropsychologia, 40, 1154-1166.

Tyler, L. K., Stamatakis, E. A., Jones, R. W., Bright, P., Acres, K., \& MARSLEN-Wilson, W. D. (2004). Deficits for semantics and the irregular past tense: A causal relationship? Journal of Cognitive Neuroscience, 16, 1159-1172.

Ullman, M. T. (2001). A neurocognitive perspective on language: The declarative/procedural model. Nature Reviews Neuroscience, 2 , 717-726.

Ullman, M. T. (2004). Contributions of memory circuits to language: The declarative/procedural model. Cognition, 92, 231-270.

Ullman, M. T., Corkin, S., Coppola, M., Hickok, G., Growdon, J. H., Koroshetz, W. J., \& Pinker, S. (1997). A neural dissociation within language: Evidence that the mental dictionary is part of declarative memory, and that grammatical rules are processed by the procedural system. Journal of Cognitive Neuroscience, 9, 266-276.

Ullman, M. T., Pancheva, R., Love, T., Yee, E., Swinney, D., \& HiскоK, G. (2005). Neural correlates of lexicon and grammar: Evidence from the production, reading, and judgment of inflection in aphasia. Brain \& Language, 93, 185-238.

Weyerts, H., Münte, T. F., Smid, H. G. O. M., \& Heinze, H.-J. (1996). Mental representations of morphologically complex words: An eventrelated potential study with adult humans. Neuroscience Letters, 206, 125-128.

Weyerts, H., Penke, M., Dohrn, U., Clahsen, H., \& Münte, T. F. (1997). Brain potentials indicate differences between regular and irregular German plurals. NeuroReport, 8, 957-962.

\section{NOTES}

1. More recent approaches have demonstrated that double dissociations can occur as the result of stochastic variation in the disruption of distributed networks that do not include such internal differentiation between phonological and semantic units (Plunkett \& Bandelow, 2006).

2. See Bartke, Rösler, Streb, and Wiese (2005) for a study comparing ERPs to different forms within the German irregular plural system.

3. The distinction between weak irregulars and strong verbs is similar but not identical to the distinction drawn by Joanisse and Seidenberg (2005) between "pseudoregulars" and "true irregulars." These authors considered some weak irregular verbs (e.g., heard, said) to be "pseudoregular" because the dental stop is present only for the past-tense form, but they considered other weak irregulars (e.g., built, sent) to be "true irregulars." The present distinction between weak irregulars and strong verbs was made based on Pinker (1999). 
APPENDIX

\begin{tabular}{|c|c|c|c|c|c|}
\hline \multicolumn{6}{|c|}{$\begin{array}{c}\text { Stimulus Listing } 1 \\
\text { Regular Verbs }\end{array}$} \\
\hline \multicolumn{2}{|c|}{ Primed } & \multicolumn{2}{|c|}{ Unprimed } & \multicolumn{2}{|c|}{ Nonword } \\
\hline Prime & Target & Prime & Target & Prime & Target \\
\hline looked & look & worked & seem & asked & tarb \\
\hline tried & try & cooled & use & called & splibe \\
\hline turned & turn & flashed & work & lived & flane \\
\hline changed & change & used & talk & moved & frar \\
\hline played & play & smoked & help & paid & rop \\
\hline liked & like & stored & stop & walked & thresk \\
\hline reached & reach & seemed & stay & watched & swoist \\
\hline hoped & hope & posed & die & loved & twieve \\
\hline killed & kill & formed & wish & picked & nunt \\
\hline caused & cause & dared & pull & raised & fruzz \\
\hline laughed & laugh & marked & serve & planned & troast \\
\hline dropped & drop & longed & fail & joined & dwarc \\
\hline forced & force & solved & face & filled & deace \\
\hline stared & stare & served & form & pushed & thean \\
\hline closed & close & kissed & cry & saved & keft \\
\hline thanked & thank & climbed & share & cared & stroob \\
\hline placed & place & failed & claim & touched & fuvv \\
\hline owned & own & wished & climb & washed & smeap \\
\hline gained & gain & died & dress & pressed & lerp \\
\hline crossed & cross & rubbed & pour & checked & gloal \\
\hline leaned & lean & screamed & cook & feared & plect \\
\hline danced & dance & hired & jump & rolled & rerns \\
\hline slipped & slip & cooked & train & stretched & heef \\
\hline stepped & step & claimed & kiss & locked & nush \\
\hline knocked & knock & sucked & solve & cleaned & stuse \\
\hline warned & warn & shared & mark & named & foob \\
\hline signed & sign & pulled & dare & mixed & prete \\
\hline waved & wave & ranged & scream & rushed & maff \\
\hline charged & charge & sensed & smoke & cleared & flerb \\
\hline kicked & kick & trained & cope & dried & frene \\
\hline paused & pause & poured & rub & dragged & frerch \\
\hline judged & judge & wrapped & fix & searched & chonze \\
\hline launched & launch & fixed & sense & switched & clett \\
\hline wiped & wipe & stopped & rule & stirred & stroute \\
\hline phoned & phone & ruled & suck & linked & dirp \\
\hline flowed & flow & helped & wrap & urged & siff \\
\hline grabbed & grab & coped & gaze & ceased & sproil \\
\hline fished & fish & stayed & long & aimed & twince \\
\hline dined & dine & dressed & hire & lacked & spript \\
\hline shocked & shock & gazed & store & matched & pliff \\
\hline viewed & view & cried & beg & slowed & hurn \\
\hline marched & march & talked & pose & weighed & broont \\
\hline squeezed & squeeze & faced & pray & drained & jamp \\
\hline grinned & grin & jumped & flash & snapped & swouth \\
\hline stressed & stress & begged & range & lined & shralt \\
\hline trapped & trap & prayed & cool & backed & yolve \\
\hline allowed & allow & agreed & appear & believed & reweff \\
\hline increased & increase & appeared & produce (v.) & remained & bethwox \\
\hline supposed & suppose & produced & return & involved & athweege \\
\hline explained & explain & returned & agree & arrived & imbrepth \\
\hline
\end{tabular}


APPENDIX (Continued)

Stimulus Listing 2

Irregular Verbs (Italics Indicate a Strong Verb or Suppletive Verb)

\begin{tabular}{|c|c|c|c|c|c|}
\hline \multicolumn{2}{|c|}{ Primed } & \multicolumn{2}{|c|}{ Unprimed } & \multicolumn{2}{|c|}{ Nonword } \\
\hline Prime & Target & Prime & Target & Prime & Target \\
\hline spent & spend & held & send & put & critt \\
\hline bent & bend & slunk & build & let & yark \\
\hline dwelt & dwell & kept & lend & set & brenge \\
\hline made & make & thought & have & cut & sponch \\
\hline bought & buy & lost & think & hit & cabe \\
\hline taught & teach & went & bring & spread & stroul \\
\hline sought & seek & swore & catch & fit & gevv \\
\hline slept & sleep & had & fight & shut & flirl \\
\hline swept & sweep & leapt & keep & hurt & crolt \\
\hline crept & creep & struck & leap & cost & wogg \\
\hline did & do & woke & weep & cast & spresh \\
\hline told & tell & lit & say & burst & chuth \\
\hline left & leave & stood & feel & split & snalph \\
\hline read (past) & read (pres.) & flew & hear & bet & croice \\
\hline led & lead & swam & lose & thrust & vev \\
\hline sold & sell & strove & meet & shed & thrume \\
\hline dealt & deal & said & feed & quit & nurk \\
\hline shot & shoot & wound & hide & knit & frew \\
\hline dreamt & dream & hid & light & bid & sploon \\
\hline bit & bite & strode & slide & wet & screrf \\
\hline bled & bleed & slung & flee & slit & stoolt \\
\hline sped & speed & caught & kneel & rid & neech \\
\hline drew & draw & shook & grow & wed & bloun \\
\hline threw & throw & heard & fly & beat & nange \\
\hline ate & eat & fed & blow & spit & twert \\
\hline chose & choose & fled & stand & knew & yick \\
\hline fell & fall & wept & hold & gave & zate \\
\hline ground & grind & slid & bind & lay & skiv \\
\hline bore & bear & sent & wind (v.) & saw & thwat \\
\hline wore & wear & trod & swear & came & swert \\
\hline got & get & blew & tread & found & stilch \\
\hline broke & break & brought & shake & tore & cluft \\
\hline spoke & speak & bound & wake & took & plinn \\
\hline wrote & write & fought & steal & froze & slart \\
\hline dove & dive & grew & weave & drove & yusk \\
\hline shone & shine & shrank & stride & rode & snaid \\
\hline smote & smite & met & strive & rose & stip \\
\hline$d u g$ & dig & felt & drink & sat & frup \\
\hline stuck & stick & knelt & strike & ran & chulb \\
\hline sang & sing & clung & swing & hung & flond \\
\hline flung & fling & built & swim & rang & glell \\
\hline stung & sting & drank & cling & sank & smen \\
\hline spun & spin & stole & shrink & won & slulp \\
\hline strung & string & wove & sling & sprang & drine \\
\hline snuck & sneak & lent & slink & wrung & nith \\
\hline was & is & swung & go & stank & thweez \\
\hline misled & mislead & forgave & mistake & arose & forsharn \\
\hline beheld & behold & awoke & begin & became & misgife \\
\hline forgot & forget & began & forgive & withdrew & aspoove \\
\hline withstood & withstand & mistook & awake & upset & betwan \\
\hline
\end{tabular}


APPENDIX (Continued)

\begin{tabular}{|c|c|c|c|c|c|}
\hline \multicolumn{6}{|c|}{$\begin{array}{c}\text { Stimulus Listing } 3 \\
\text { Pseudopast }\end{array}$} \\
\hline \multicolumn{2}{|c|}{ Primed } & \multicolumn{2}{|c|}{ Unprimed } & \multicolumn{2}{|c|}{ Nonword } \\
\hline Prime & Target & Prime & Target & Prime & Target \\
\hline and & an & that & the & but & boathe \\
\hline bald & ball & sane & rock & live (adj.) & sepp \\
\hline bade & bay & mar & hut & clip & bife \\
\hline bead & bee & bulb & pie & deer & cleeth \\
\hline brand & bran & flint & clam & spine & snace \\
\hline bird & burr & milk & cask & star & snoss \\
\hline card & car & boat & lot & park & ghipt \\
\hline chest & chess & throat & ounce & nurse & crarge \\
\hline cold & coal & hard & tool & dark & stebb \\
\hline cord & core & disc & horn & dose & crume \\
\hline deft & deaf & scant & $\operatorname{limp}$ & meek & scrurn \\
\hline feud & few & moat & end & yawn & whoam \\
\hline fund & fun & drug & luck & bath & bloy \\
\hline guild & gill & glare & din & grunt & breap \\
\hline gold & goal & yard & suit & farm & braff \\
\hline grade & gray & score & fair & stove & polk \\
\hline guide & guy & match & joy & drain & pess \\
\hline heed & he & reek & she & rove & rerg \\
\hline jade & jay & gist & sow & peel & narve \\
\hline need & knee & move & shoe & walk & thrail \\
\hline laud & law & vend & arm & shirk & vapse \\
\hline lest & less & whilst & most & till & shrist \\
\hline load & low & trace & hot & dawn & splard \\
\hline mead & me & fang & my & scab & frane \\
\hline mend & men & arch & girl & dust & stask \\
\hline mild & mile & loud & tree & neat & twark \\
\hline mold & mole & globe & crate & flock & smool \\
\hline $\operatorname{mood}$ & moo & sake & caw & cash & spink \\
\hline next & necks & flat & means & rare & spirp \\
\hline nude & new & tame & old & lame & slisp \\
\hline proud & prow & tight & node & rough & crus \\
\hline raid & ray & coin & pin & sack & smav \\
\hline rift & riff & hush & char & flux & ghump \\
\hline ride & rye & lock & fig & name & fland \\
\hline shrewd & shrew & poised & sieve & scarce & gwufe \\
\hline tend & ten & plan & nine & join & thwoll \\
\hline toad & toe & snail & mud & kite & wump \\
\hline tuft & tough & pail & firm & yolk & wouce \\
\hline trade & tray & death & rail & front & dern \\
\hline ward & war & pipe & eye & bait & seff \\
\hline weed & wee & soup & shrill & dirt & swoust \\
\hline weld & well & deem & down & rake & smec \\
\hline wend & when & void & where & punt & frult \\
\hline wide & why & huge & whose & rich & snound \\
\hline wind (n.) & win & hill & act & film & feck \\
\hline rend & wren & snub & cone & oust & dwoss \\
\hline buzzard & buzzer & drunkard & cracker & placard & fusker \\
\hline leopard & leper & hazard & lumber & steward & striner \\
\hline mustard & muster & orchard & shower & coward & shrounder \\
\hline tankard & tanker & wizard & dagger & billiard & stulper \\
\hline
\end{tabular}


APPENDIX (Continued)

\begin{tabular}{|c|c|c|c|c|c|}
\hline \multicolumn{6}{|c|}{$\begin{array}{c}\text { Stimulus Listing } 4 \\
\text { Orthophono }\end{array}$} \\
\hline \multicolumn{2}{|c|}{ Primed } & \multicolumn{2}{|c|}{ Unprimed } & \multicolumn{2}{|c|}{ Nonword } \\
\hline Prime & Target & Prime & Target & Prime & Target \\
\hline barge & bar & bribe & tea & pouch & gwal \\
\hline binge & bin & spurt & vat & troll & gwech \\
\hline blurb & blur & dirge & halt & mulch & gloach \\
\hline bowl & bow (n.) & debt & spy & port & pright \\
\hline breadth & bread & stench & brain & fridge & nulk \\
\hline brown & brow & green & duck & black & froin \\
\hline bump & bum & flap & ale & pace & gank \\
\hline bunch & bun & hedge & hue & stamp & splift \\
\hline chump & chum & wench & hive & cinch & cleal \\
\hline conch & con & grove & row & blast & yeel \\
\hline cramp & cram & graft & boom & smirk & scroign \\
\hline dense & den & steep & kit & harsh & plape \\
\hline farce & far & blaze & yet & brook & smenth \\
\hline feet & fee & line & toy & food & throg \\
\hline finch & fin & drawl & nod & crock & sern \\
\hline flute & flu & flare & gut & plume & sloont \\
\hline forth & for & north & off & twice & stend \\
\hline gasp & gas & curl & cup & prop & sharce \\
\hline hemp & hem & jest & kin & kilt & brulk \\
\hline hence & hen & south & fox & wrong & thague \\
\hline hump & hum & salt & hug & mine & nake \\
\hline inch & in & fuel & on & sand & slarf \\
\hline paint & pain & clean & list & count & rird \\
\hline pant & pan & howl & ton & mock & gwoint \\
\hline parch & par & chime & pod & strut & gruck \\
\hline pawn & paw & mast & nap & chef & clull \\
\hline peach & pea & bloom & $\operatorname{cod}$ & snack & clist \\
\hline pierce & pier & bruise & toll & sprawl & rask \\
\hline plump & plum & blank & hawk & tense & flince \\
\hline prompt & prom & scrape & helm & stroll & clis \\
\hline punch & pun & perch & bib & whirl & blit \\
\hline ramp & ram & cork & web & stag & smoob \\
\hline rump & rum & sill & rig & grub & snoave \\
\hline scarf & scar & stack & barn & spear & chich \\
\hline shunt & shun & blare & pout & spank & shabe \\
\hline sight & sigh & stone & rent & staff & pheech \\
\hline since & $\sin$ & quite & pot & still & slont \\
\hline skimp & skim & stash & stab & rhyme & plail \\
\hline slump & slum & drape & chat & swarm & slast \\
\hline sparse & spar & quaint & huff & blonde & ploam \\
\hline sunk & sun & sprung & top & sung & ninge \\
\hline tart & $\operatorname{tar}$ & wisp & vet & loot & treeb \\
\hline tint & tin & swig & cow & yarn & zix \\
\hline twinge & twin & spouse & loan & crutch & zaist \\
\hline youth & you & noise & his & shape & fowd \\
\hline zoom & zoo & mime & fog & dent & tratt \\
\hline every & ever & other & never & either & speemer \\
\hline pattern & patter & section & pamper & chapter & jadgeon \\
\hline several & sever & further & quiver & neither & lafer \\
\hline against & again & without & away & between & ashroon \\
\hline
\end{tabular}

(Manuscript received January 16, 2007 ;

revision accepted for publication December 9, 2007.) 